Annals of Warsaw University of Life Sciences - SGGW

Land Reclamation No 42 (2), 2010: 279-293

(Ann. Warsaw Univ. of Life Sci. - SGGW, Land Reclam. 42 (2), 2010)

\title{
Parameter identification of a conceptual rainfall-runoff model for a small urban catchment
}

\author{
ANNA SIKORSKA, KAZIMIERZ BANASIK \\ Department of Water Engineering and Environmental Restoration, \\ Warsaw University of Life Sciences - SGGW
}

\begin{abstract}
Parameter identification of a conceptual rainfall-runoff model for a small urban catchment. As a consequence of city expansion, the conditions of catchments located in urban areas have been permanently changing. This leads to an increase of flood risk in an urban area resulting from overflows of small streams, which are not prepared to receive more water. Moreover, hydrological data from long-time period are usually not available for small streams in an urban area and are limited to the last few years or to the moment after introduced changes within catchment in relation to urbanization. Therefore, it becomes hardly possible to use direct methods of estimating flood flows for small streams, which needs a reach data set. For that reason, mathematical modelling is growing as a basic method of evaluation of flood flows in urban area with limited information of a catchment.

The object of this paper is to identify parameters of a conceptual model of rainfall-runoff process within a small ungauged urban catchment and to verify how chosen characteristics of a model depend on chosen rainfall characteristics. The results of modelling of pluvial flooding, conducted in a small urban catchment - Służew Creek catchment (located in Warsaw, Poland), have been presented in the paper. This catchment has been monitored by Department of Water Engineering and Environmental Restoration (Warsaw University of Life Sciences - SGGW) for a few years.

Next, the results present a comparison of estimation of instantaneous unit hydrograph (IUH) by the Rao, Delleur and Sarma equations with the one established on recorded data. This empirical method consists of the ratio of urbanized area within catchment as well as in the duration and amount of an effective rainfall during a storm event. Moreover, including ratio of urbanized area
\end{abstract}

allows user to adopt this method in a simple way to new conditions of the catchment, which is important as far as urban areas are considered.

Considered IUHs were based on the Nash model, in which catchment is depicted as a cascade of $\mathrm{N}$ linear reservoirs with the same retention parameter k. For separation of the effective rainfall from the recorded storm the CN-SCS method was applied. To compare two methods, IUHs were estimated basing on three hydrological years (2007-2009) for a Berensewicz Pond profile and the comparison was made on the base of an IUH characteristic value - Lag time.

The results of identification and verification of characteristics values of IUH (Lag and k) for Służew Creek catchment, presented in this paper, have indicated a statistical correlation between lag time and the sum of total and effective precipitation, and between $\mathrm{k}$ parameter and the sum of total and effective precipitation as well. Moreover, the analysis has shown that IUH characteristics estimated with the use of Rao, Delleur and Sarma equation has given promising results in comparison with the characteristics of measured IUH. Therefore, this method could be useful to estimate and predict flood flows in ungauged urban catchments in situation of limited information. However, this research needs further investigation and verification.

Key words: instantaneous unit hydrograph - IUH, Nash model, Rao, Delleur and Sarma equations, $\mathrm{CN}-\mathrm{SCS}$, gauged catchment, lag time.

\section{INTRODUCTION}

Small urban streams need a special treatment in hydrology regarding the process 
of urbanization, which can often change the behaviour of a stream from a slow and reduced response to a rapid and higher in costs one. Consequently, the same rainfall event, which, before the urbanization was discharged by a stream without even being noticed by local people, can cause local overflows, which brings a high economical and social loss. The significant problem for hydrologists with such small urban streams and ungauged catchments is usually a lack of recorded data from a long period (historical). (Ungauged catchments - catchments with the absence of data required for parameter estimation for either existing or future conditions, Engineer Manual 1994.) Therefore, it becomes hardly possible to use direct methods of estimating flood flows. To estimate runoff from an ungauged catchment, for existing or forecasted-future conditions, a hydrologist can apply a model that includes only parameters that can be observed or inferred from measurements, or extrapolate parameters from parameters found for gauged catchments within the same region (Engineer Manual, 1994). For that reason, mathematical modelling with conceptual models with limited number of physically based parameters (which can be observed or estimated directly from measurements of catchment or channel characteristics without in opposite to calibration parameters - lumped, single-valued parameters that have no direct physical significance and must be estimated from rainfall and runoff data, Engineer Manual 1994) is growing to a basic tool for evaluation of flood flows in an urban area with limited information of the catchment. Moreover, hydrologists have gone further and given a first place to conceptual models with reasonably estimated parameters rather than to more complex models with unsure parameters or fixed on the basis of unsure data (Dooge 2005; Beven and Kirkby 1979).

The results of pluvial flooding modelling, conducted in a small urban catchment - Służew Creek catchment (located in Warsaw, Poland), is an object of this paper. This watershed has been monitored by Department of Water Engineering and Environmental Restoration (Warsaw University of Life Sciences - SGGW) since a few years.

Among conceptual models of transformation of an effective rainfall, which occurs in a catchment, into a direct runoff, observed in the outlet, the most common used is the Nash model of Instantaneous Unit Hydrograph (IUH). This method establishes that for a given catchment, effective rainfalls with the same sum of precipitation (when intensive and duration of the rainfall are constant) cause floods with the same behaviour in respect to time.

This paper presents results of an identification of conceptual model for Stużew Creek catchments, a verification of how chosen characteristics of a model depend on chosen rainfall characteristics, and a comparison for this catchment of empirical methods of estimating of Instantaneous Unit Hydrograph (IUH) by Nash model - Rao, Delleur and Sarma, with the one based on recorded data from three hydrological years (2007-2009). The Rao et al. method has been employed in research to estimate possibilities of applying this method in small urban catchment with partly or without any recorded data in the catchment. The comparison was made based on characteristic values in IUH (Lag) in both methods. 
In author's previous research, the Rao et al. method of estimating IUH was adopted, which gives the best fit to the IUH evaluated on the basis of observed data. The analysis was conducted for three empirical methods (also SCS and Lutz method) and for a shorter period of an observation (2007-2008) (Sikorska and Banasik 2008a).

The aim of the conducted analysis was to verify the chosen characteristics of the model and their dependence on chosen rainfall characteristics, and to assess possible application of Rao et al. method in estimating IUH in predicting flood flows in situation of limited information about the catchment.

\section{UNIT HYDROGRAPH APPROACH}

The unit hydrograph (Sherman 1932; Dooge 1959; Singh 1988; Beven 2000; Jovanovic 2000; Jeng and Coon 2002; Banasik et al. 2007; Sikorska and Banasik 2008a, 2008b, 2009) represents a direct runoff at the outlet of a catchment resulting from one unit of an effective precipitation excess over the catchment. The excess occurs at a constant intensity over a specified duration, and when the duration aims to zero, the unit hydrograph takes a name of instantaneous unit hydrograph (IUH).

The unit hydrograph approach considers that: precipitation excess and losses can be treated as basin-average (lumped) quantities, the ordinates of a direct runoff hydrograph corresponding to precipitation excess of a given duration are directly proportional to the volume of excess (assumption of linearity), and the direct runoff hydrograph resulting from a given increment of precipitation excess is independent from the time of occurrence of the excess (assumption of time invariance) (Engineer Manual, 1994).

The advantage of this approach is the simple way to estimate parameters, which in the unchanged condition of the catchment stay constant. Moreover, the estimation of IUH for the given catchment allows user to employ this hydrograph to any rainfall event occurs in the catchment and consequently to an estimation of a response of the catchment. However, in that case, a proper evaluation of the parameters arises to the most important step of the evaluation of a model (Dooge 1959).

From the available methods transformative effective rainfall into direct runoff the most widely used and effective in selection of parameters, in situation of limited data of an urban catchment (Banasik et al. 2000), is the IUH based on the Nash model, in which catchment is depicted as a cascade of $\mathrm{N}$ linear unique reservoirs with retention parameter $k$ of each reservoir - Fig. 1 (a linear reservoir is a reservoir for which there is a linear relationship between storage and outflow, Nash 1957):

$u(t)=\frac{1}{k \cdot \Gamma(N)} \cdot\left(\frac{t}{k}\right)^{N-1} \exp \left(-\frac{t}{k}\right)$

Where:

$u(t)$ - ordinates of IUH $\left[\mathrm{h}^{-1}\right]$,

$t$-time from the beginning of coordinate system [h],

$N, k$ - Nash model parameters;

$N$-number of linear reservoirs [-],

$k$ - retention parameter of each reservoir

[h],

$\Gamma(N)$ - gamma function. 

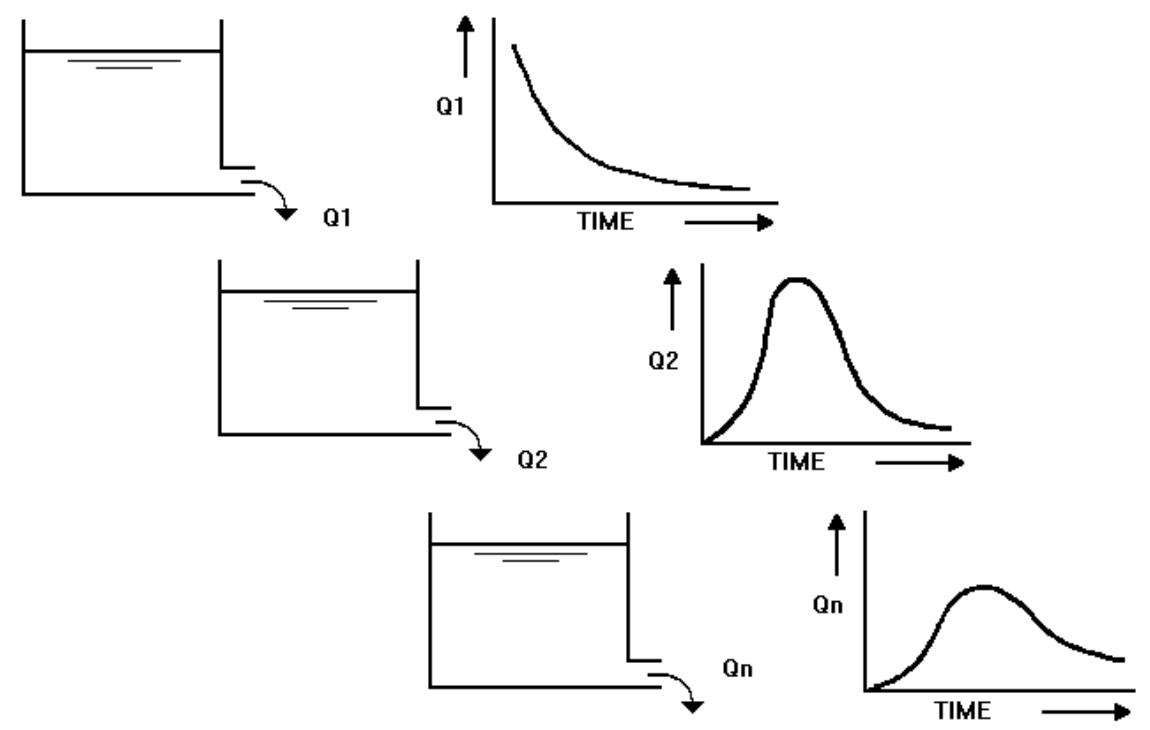

FIGURE 1. A concept of a Nash model - cascade of linear reservoirs (Engineer Manual, 1994)

The characteristic values of IUH hydrograph are peak and time to peak, which are estimated as a function of the time of concentration (the time required for a drop of water to travel from the most hydrologically remote point in the sub-catchment to the point of collection SCS, 1986). The relation between IUH characteristics $\left(t_{p}\right.$ and $\left.u_{p}\right)$ and parameters ( $\mathrm{N}$ and $\mathrm{k}$ ) is described, as follows:

$t_{p i}=k_{i} \cdot\left(N_{i}-1\right)$

$u_{(t p i)}=\frac{1}{k_{i} \cdot \Gamma\left(N_{i}\right)} \cdot \frac{\left(N_{i}-1\right)^{N i-1}}{\exp \left(N_{i}-1\right)}$

Where:

$N_{i}$ - number of linear reservoirs for $i-$ IUH $[-]$

$k_{i}$ - retention parameter of reservoir for $i-$ IUH [h].

The IUH parameters $(\mathrm{N}, \mathrm{k})$ are quite often investigated and relatively easy to establish by the method of statistical moments by the relations:

$$
M_{1 Q}-M_{1 P}=N \cdot k
$$

$M_{2 Q}-M_{2 P}=N \cdot k^{2} \cdot(N+1)+2 N \cdot k \cdot M_{1 P}$

Where $M_{1 Q}$ and $M_{1 P}$ are first statistical moments, $M_{2 Q}$ and $M_{2 P}$ second statistical moments, of the direct runoff hydrograph and the effective rainfall hyetograph respectively. Another significant characteristic value in rainfall-runoff modelling is the lag time of direct runoff (time of response). Lag, which is described as the time elapsed between the centroids of the effective rainfall hyetograph and the direct runoff hydrograph (Fig. 2, Barszcz et al. 2006).

The lag time is estimated, using the method of statistical moments, by formula, as follows: 


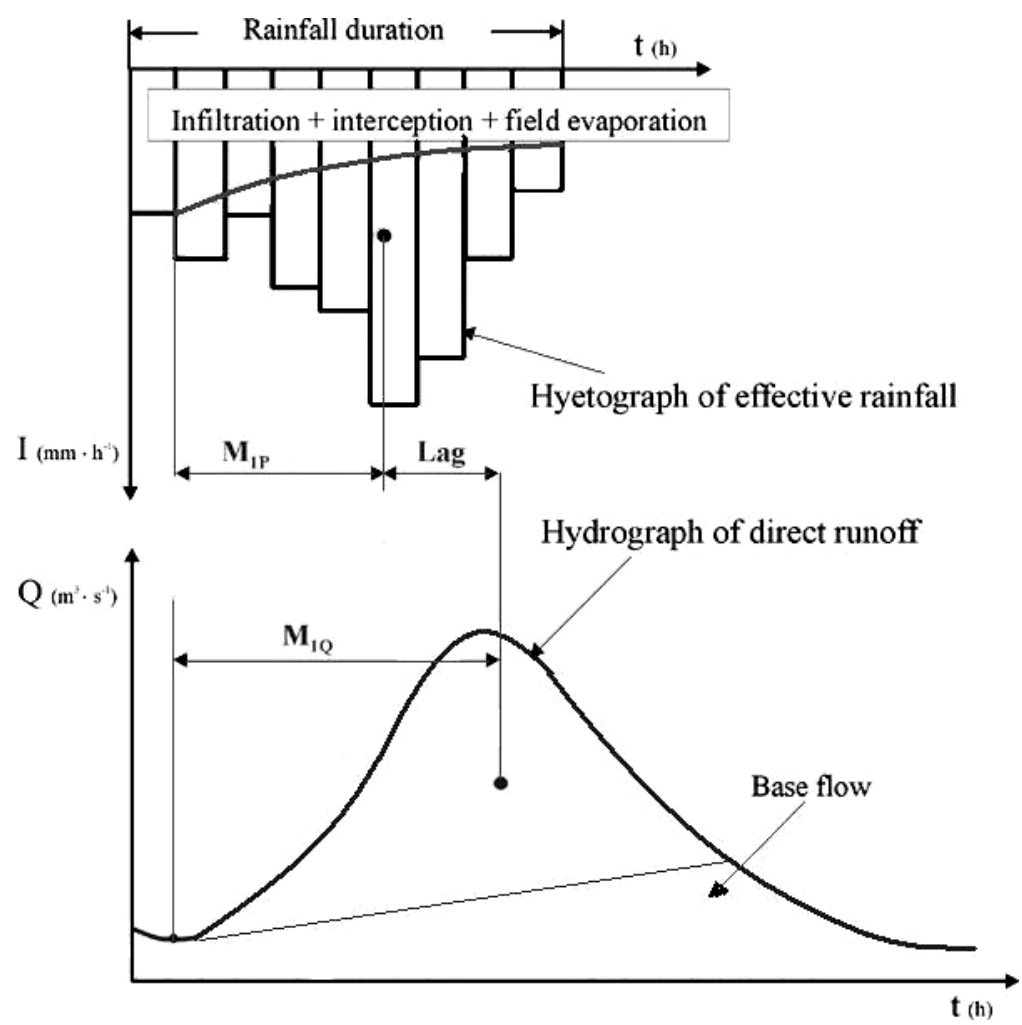

FIGURE 2. Idea of an estimation of Lag time (Barszcz et al. 2006 - in modification by author)

$$
\operatorname{Lag}=M_{1 Q}-M_{1 P}
$$

And for the IUH derived from Nash model the relationship between the lag time of runoff and IUH parameters is expressed by:

$$
\operatorname{Lag}=N \cdot k
$$

\section{RAO ET AL. METHOD}

A promising method of a transformation of rainfall into runoff in situation of changing conditions of a catchment is Rao, Delleur i Sarma approach (Rao et al. 1972), developed for small urban catchments. Rao et al. has introduced method, in which IUH characteristic values (Lag and $\mathrm{k}$ ) are dependent on the value of a total area of a catchment, the ratio of urbanised areas in the catchment and duration and a sum of an effective rainfall. This methos has been commonly applied in hydrology by many researchers (e.g. Jovanovic 1986, Banasik et al. 2007; Sikorska and Banasik 2008a, 2008b, 2009):

$$
\begin{array}{r}
\operatorname{Lag}=1.28 \cdot A^{0.46} \cdot(1+U)^{-1.66} \cdot H^{-0.27} \cdot D^{0.37} \\
k=0.56 \cdot A^{0.39} \cdot(1+U)^{-0.62} \cdot H^{-0.11} \cdot D^{0.22}
\end{array}
$$


Where:

Lag - lag time [h],

$k$ - linear reservoir retention parameter

[h],

$A$ - catchment area $\left[\mathrm{km}^{2}\right]$,

$U$ - fraction of the impervious area in the catchment [-],

$H$ - effective rainfall [mm],

$D$ - effective rainfall duration [h].

The parameters of Nash model can be calculated as a modification of equation no 5 and 6 , as follows: $N=\frac{L a g}{k} ; t_{P}=(N-1) \cdot k$

The advantage of this method in comparison with other simple method in rainfall-runoff modelling (e.g. SCS and Lutz methods; SCS 1986; Lutz 1984) is the possibility to modify parameters of a catchment, due to land-use changes, which is important as far as urban areas are concerned.

\section{CASE STUDY - SŁUŻEW CREEK}

Służew Creek is a receiver for rainfall in south-western Warsaw. The absolute area of the Służew Creek catchment to its outlet to Wilanowskie Lake is about 53.7 $\mathrm{km}^{2}$ and the area of the catchment to the Berensewicz Pond water stream, which is the object of this analysis $-26.9 \mathrm{~km}^{2}$ (KIWRS, 2002). Within the catchment, there are observed areas with a stronger urbanisation level as airport Okęcie and industrial areas in Ochota and Ursynów districts of Warsaw, and areas which have still more agricultural character as Grabów and Pyrów areas within Ursynów district and Kabacki Forest (Ursynów). Looking at the catchment, the north part from the catchment is more urbanised, and a south part (Grabowski Ditch inlet) has a lower ratio of urbanisation. In this paper, the catchment was assumed as a whole without any division for sub-catchments, and the ratio of urbanisation was established basing on a specification of land use, as a percent of impervious areas, on the level of 0.237 (Sikorska and Banasik 2009).

\section{SAMPLING DATA AND METHODOLOGY}

Rainfall data (from three rain gauging stations - Okęcie, Kajakowa and Ursynów - SGGW, Figure 3) and direct runoff data at the Berensewicz Pond stream gauge were collected during three hydrological years: 2007-2009. Both rainfall and runoff data (water level data) were recorded automatically with 10 minutes intervals. To estimate water discharge on the basis on water level, the stage-discharge curve estimated by hydrometric measurements was employed. The recorded data were verified during the period of the measurement by an observer.

Analysis has been conducted for chosen events with the flood flow equal or higher then the five-times value of the average flow at Berensewicz Pond stream gauge $\left(0.2 \mathrm{~m}^{3} / \mathrm{s}\right.$, KIWRS, 2002). For separation of the effective rainfall from the recorded storm for each chosen event, the CN-SCS method was applied. During the period of 2007-2009 (hydrological years), there were 31 storm events observed with maximum discharge equal or higher than $1.0 \mathrm{~m}^{3} / \mathrm{s}$, from which 3 events were discarded in addition to the shape of hydrograph, which put the natural shape of hydrograph into doubts 


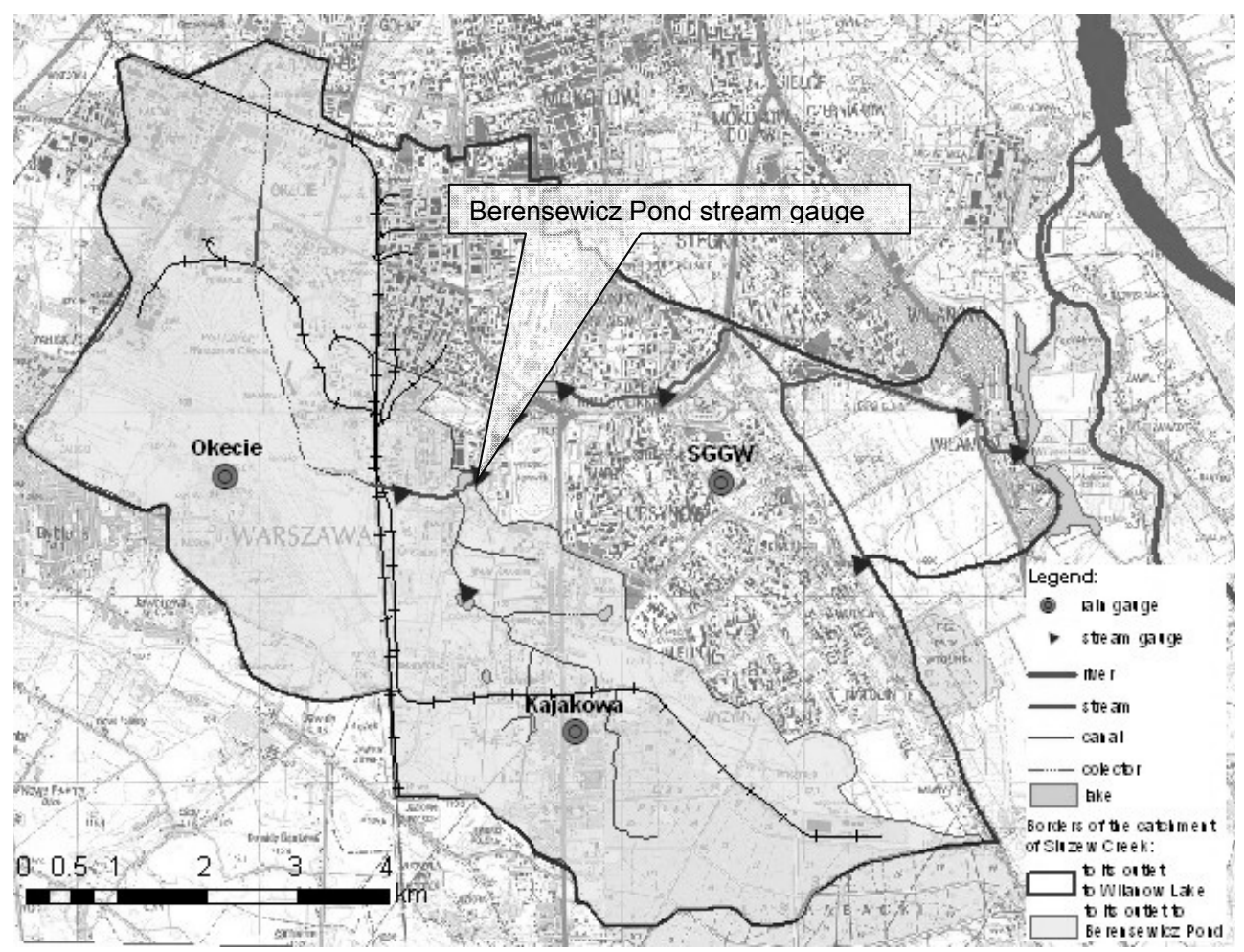

FIGURE 3. Locality of the Służew Creek catchment upstream of the gauge of Berensewicz Pond

(regarding to the possible suppression of discharge on the outlet - under a culvert), and 6 regarding the duration of the rainfall (higher than 12 hours). For the remaining 22 events, the parameters and characteristics IUH for each event were estimated on the basis of rainfall and runoff recorded data by the method of statistical moments by the equations 4-7 (Tab. 1). The average value of the IUH peak and time to IUH peak were estimated as arithmetic mean from the formulae:

$$
\overline{t_{p}}=\frac{\sum_{i=1}^{m} t_{p i}}{m}
$$

$$
\overline{u_{t p}}=\frac{\sum_{i=1}^{m} u_{p i}}{m}
$$

where:

$\overline{t_{p}}$ - average time to IUH peak $[\mathrm{h}]$,

$\overline{u_{t p}}-$ average IUH peak $\left[\mathrm{h}^{-1}\right]$,

$t_{p i}$ - value of time to IUH peak for $i$-event [h],

$u_{t p i}$ - value of IUH peak for i-event $\left[\mathrm{h}^{-1}\right]$, $m$ - number of hydrographs.

Concerning Lag time parameter, a statistical correlation between lag time and the sum of precipitation was observed (total and effective as well), for events with a higher sum of precipitation lag time is longer comparing with events 


\begin{tabular}{|c|c|c|c|c|c|c|c|c|c|c|c|c|c|c|c|c|c|}
\hline \multirow{3}{*}{ 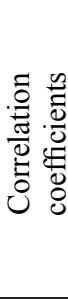 } & $\begin{array}{l}\sqrt{0} \\
\frac{1}{2} \\
\underline{2}\end{array}$ & $\stackrel{0}{0}$ & in & $\ddot{m}$ & ? & $r$ & 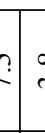 & in & ì. & $\stackrel{\sim}{+}$ & ले & $\vec{i}$ & $\vec{r}$ & $\stackrel{n}{+}$ & $m$ & $\stackrel{\Upsilon}{+}$ & $\stackrel{a}{\infty}$ \\
\hline & $\approx$ & ơ & 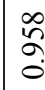 & $\begin{array}{l}0 \\
\alpha \\
0\end{array}$ & ฮั & ร & 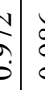 & : & $\begin{array}{l}1 \\
\text { ô } \\
0 \\
0\end{array}$ & $\begin{array}{l}\text { T. } \\
\hat{a} \\
0\end{array}$ & $\begin{array}{l}\bar{\sigma} \\
\hat{\sigma}\end{array}$ & $\begin{array}{l}\infty \\
\stackrel{\alpha}{0}\end{array}$ & $\begin{array}{l}\infty \\
\tilde{\sigma} \\
0\end{array}$ & 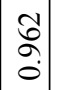 & $\begin{array}{l}\bar{n} \\
\hat{o}\end{array}$ & مे & $\stackrel{\infty}{\sigma}$ \\
\hline & $\simeq$ & $\begin{array}{l}\infty \\
\infty \\
\infty \\
0\end{array}$ & $\begin{array}{l}\check{2} \\
\infty \\
0\end{array}$ & ईิ & 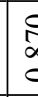 & $\bar{z}$ & 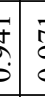 & 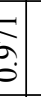 & 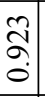 & $\begin{array}{l}\hat{\sigma} \\
\hat{\sigma}\end{array}$ & 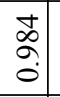 & $\begin{array}{l}2 \\
\delta \\
\delta\end{array}$ & $\begin{array}{l}0 \\
\hat{0} \\
0 \\
0\end{array}$ & \begin{tabular}{|l|}
$\bar{\sigma}$ \\
0
\end{tabular} & $\begin{array}{l}0 \\
\vdots \\
0 \\
0\end{array}$ & $\begin{array}{l}8 \\
8 \\
0 \\
0\end{array}$ & $\begin{array}{c}0 \\
\dot{q} \\
0 \\
0\end{array}$ \\
\hline \multirow{2}{*}{ 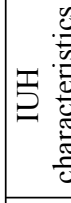 } & $\rightrightarrows \Xi$ & के & $=$ & $\frac{1}{c}$ & $\bar{c}$ & 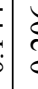 & 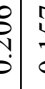 & $i$ & $\begin{array}{l}\vec{n} \\
\dot{0}\end{array}$ & $\begin{array}{l}\text { ô } \\
0 \\
0\end{array}$ & $\begin{array}{c}\infty \\
\stackrel{1}{+} \\
0\end{array}$ & ?ึ. & $\stackrel{m}{=}$ & ò & $\begin{array}{l}\exists \\
\vdots \\
\vdots\end{array}$ & $\stackrel{ \pm}{\oplus}$ & तิ \\
\hline & $=3$ & $\stackrel{\circ}{i}$ & $\begin{array}{l}\infty \\
\infty \\
i\end{array}$ & $\ddot{z}$ & ? & 5 & o & है & $\begin{array}{l}\infty \\
\infty \\
\dot{m}\end{array}$ & $\vec{r}$ & $\stackrel{1}{0}$ & $\stackrel{?}{-}$ & $\begin{array}{l}a \\
+ \\
+\end{array}$ & $\stackrel{i}{i}$ & $\stackrel{\circ}{\stackrel{\circ}{m}}$ & in & $\stackrel{\varkappa}{\sigma}$ \\
\hline \multicolumn{2}{|c|}{ 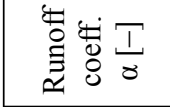 } & $\stackrel{8}{\circ}$ & $\stackrel{\circ}{=}$ & $\frac{\pi}{3}$ & o & 5 & $c$ & $\frac{8}{8}$ & \begin{tabular}{l}
$m$ \\
\hdashline \\
0
\end{tabular} & $\frac{+}{2}$ & $\begin{array}{c}\tilde{2} \\
\stackrel{0}{0}\end{array}$ & $\stackrel{0}{\stackrel{0}{*}}$ & $\stackrel{0}{0}$ & $\vec{\exists}$ & $\vec{m}$ & $\stackrel{?}{0}$ & Ŝ \\
\hline \multicolumn{2}{|c|}{$\stackrel{\substack{\Phi \\
\Xi}}{\ddot{z}} \Xi$} & $\stackrel{\vec{i}}{i}$ & \begin{tabular}{l}
$\infty$ \\
\multirow{2}{0}{} \\
0
\end{tabular} & $\stackrel{\bullet}{\infty}$ & $\frac{5}{4}$ & $\delta$ & $\$$ & ó & 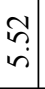 & $\stackrel{?}{r}$ & 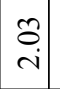 & $\stackrel{\text { f }}{\mathrm{i}}$ & $\stackrel{?}{\sim}$ & $\stackrel{\infty}{m}$ & 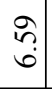 & $\begin{array}{l}\tilde{D} \\
\infty \\
i\end{array}$ & $\stackrel{m}{m}$ \\
\hline \multirow{2}{*}{ 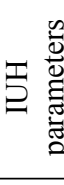 } & $\underset{\Xi}{\Xi}$ & : & $\stackrel{m}{m}$ & t & 7 & 7 & $\bar{?}$ & S. & $\stackrel{?}{:}$ & ஸे. & $\overline{-}$ & $\begin{array}{l} \pm \\
\infty \\
\infty\end{array}$ & $\stackrel{+}{i}$ & $\begin{array}{c}\overrightarrow{0} \\
\dot{n}\end{array}$ & $\underset{q}{q}$ & $\stackrel{\mathbb{N}}{\mathrm{i}}$ & $\stackrel{+}{-}$ \\
\hline & $\frac{T}{Z}$ & $\underset{r}{\stackrel{r}{r}}$ & $\stackrel{\circ}{\stackrel{2}{=}}$ & i & 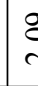 & 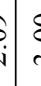 & s. & กิ & $\stackrel{\vec{c}}{\mathrm{n}}$ & $\begin{array}{l}n \\
i \\
i\end{array}$ & $\stackrel{\circ}{-}$ & $\stackrel{t}{i}$ & ک઼̆ & 守 & $\stackrel{\infty}{-}$ & ஸे & $\stackrel{+}{i}$ \\
\hline \multicolumn{2}{|c|}{ z记工 } & స్ & \begin{tabular}{l}
$n$ \\
\multirow{2}{f}{} \\
$\infty$ \\
$\infty$
\end{tabular} & $\frac{0}{d}$ & $\delta$ & $\delta$ & $t 5$ & 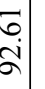 & $\begin{array}{l}0 \\
\vdots \\
\text { a }\end{array}$ & $\begin{array}{l}\bar{a} \\
\dot{\alpha}\end{array}$ & 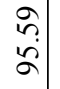 & $\begin{array}{l}\stackrel{0}{n} \\
\stackrel{2}{a}\end{array}$ & 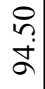 & $\mid \begin{array}{c}0 \\
0 \\
\infty \\
\infty\end{array}$ & $\begin{array}{l}0 \\
\frac{1}{2}\end{array}$ & $\stackrel{7}{a}$ & ஷें \\
\hline \multirow{2}{*}{ 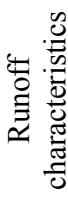 } & 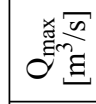 & $\begin{array}{l}\text { in } \\
\text { i }\end{array}$ & $\stackrel{8}{\stackrel{2}{:}}$ & $\stackrel{7}{7}$ & 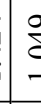 & is & $\begin{array}{l}0 \\
\vdots \\
t\end{array}$ & $\frac{m}{3}$ & 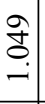 & ڤે & $\begin{array}{l} \pm \\
\stackrel{-}{ \pm} \\
\end{array}$ & i? & 煦 & $\begin{array}{c}\hat{6} \\
6 \\
i\end{array}$ & 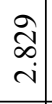 & 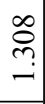 & $\stackrel{+}{0}$ \\
\hline & 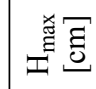 & $\stackrel{\infty}{\stackrel{+}{\Xi}}$ & $\begin{array}{l}\infty \\
\stackrel{\infty}{i} \\
\underline{-}\end{array}$ & ஓे & i & $\delta$ & $\begin{array}{l}y \\
i\end{array}$ & ¿্. & $\begin{array}{l}\infty \\
\dot{0} \\
\stackrel{1}{0}\end{array}$ & $\begin{array}{l}\stackrel{?}{+} \\
\stackrel{ \pm}{ \pm}\end{array}$ & $\underset{\infty}{\tilde{N}}$ & $\vec{\circ}$ & $\overrightarrow{8}$ & $\begin{array}{l}0 \\
\text { i } \\
\text { - }\end{array}$ & $\begin{array}{l}n \\
\mathfrak{n} \\
n\end{array}$ & $\begin{array}{l}0 \\
\dot{\infty} \\
\infty\end{array}$ & $\frac{9}{2}$ \\
\hline \multirow{4}{*}{ 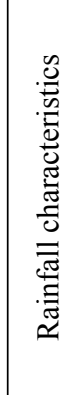 } & - 买 & $\stackrel{8}{9}$ & $\stackrel{n}{m}$ & $\begin{array}{l}\text { i } \\
\text { in }\end{array}$ & $\underline{\alpha}$ & 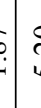 & 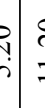 & & $\stackrel{m}{m}$ & $\stackrel{?}{+}$ & $\stackrel{9}{=}$ & 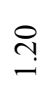 & $\stackrel{\leftrightarrow}{\rightarrow}$ & 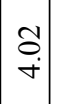 & 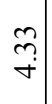 & ఠ్లి & 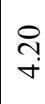 \\
\hline & Q $\Xi$ & $\stackrel{\circ}{\text { i. }}$ & $\begin{array}{l}n \\
\text { in }\end{array}$ & $\stackrel{\circ}{i}$ & is & 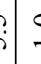 & 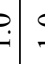 & P. & $\stackrel{\dot{m}}{\dot{m}}$ & $\tilde{m}$ & $\stackrel{n}{\sim}$ & $\stackrel{\circ}{\sim}$ & $\stackrel{\circ}{+}$ & ? & $?$ & $\stackrel{\circ}{-}$ & in \\
\hline & 土亶 & ¿ & $\stackrel{s}{i}$ & $\underset{\sim}{\infty}$ & 2 & i & $\dot{0}$ & $\stackrel{0}{\circ}$ & $\stackrel{\circ}{-}$ & $\stackrel{\infty}{i}$ & กี & $\stackrel{0}{0}$ & $\vec{\unlhd}$ & $\begin{array}{c}\hat{\sigma} \\
\dot{n}\end{array}$ & 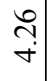 & $\begin{array}{l}\infty \\
0 \\
0\end{array}$ & $\stackrel{0}{0}$ \\
\hline & 中宧 & in & $\stackrel{+}{\infty}$ & ב & s. & & $y=$ & ב. & $\stackrel{\nabla}{\circ}$ & $\stackrel{\nabla}{a}$ & $\vec{n}$ & $\stackrel{\circ}{r}$ & $\stackrel{\infty}{\sim}$ & $\vec{b}$ & $\stackrel{n}{n}$ & ?ึ. & $\stackrel{n}{\varrho}$ \\
\hline \multicolumn{2}{|c|}{ 气ึّ } & ه্. & 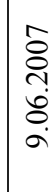 & 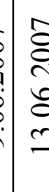 & है & 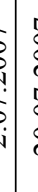 & 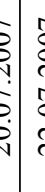 & 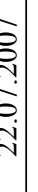 & 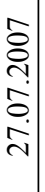 & 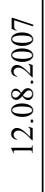 & 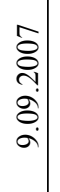 & $\begin{array}{l}\hat{0} \\
\stackrel{0}{0} \\
0 \\
0 \\
0\end{array}$ & 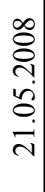 & $\left|\begin{array}{c}0 \\
0 \\
0 \\
\vdots \\
0 \\
0 \\
-1\end{array}\right|$ & 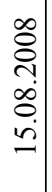 & 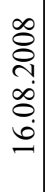 & 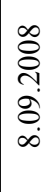 \\
\hline \multicolumn{2}{|c|}{ 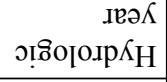 } & & \multicolumn{5}{|c|}{00} \\
\hline & 2 & - & N & $m$ & 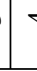 & & 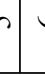 & & r & $\infty$ & $a$ & 으 & $=$ & & $=$ & \pm & $\because$ \\
\hline
\end{tabular}




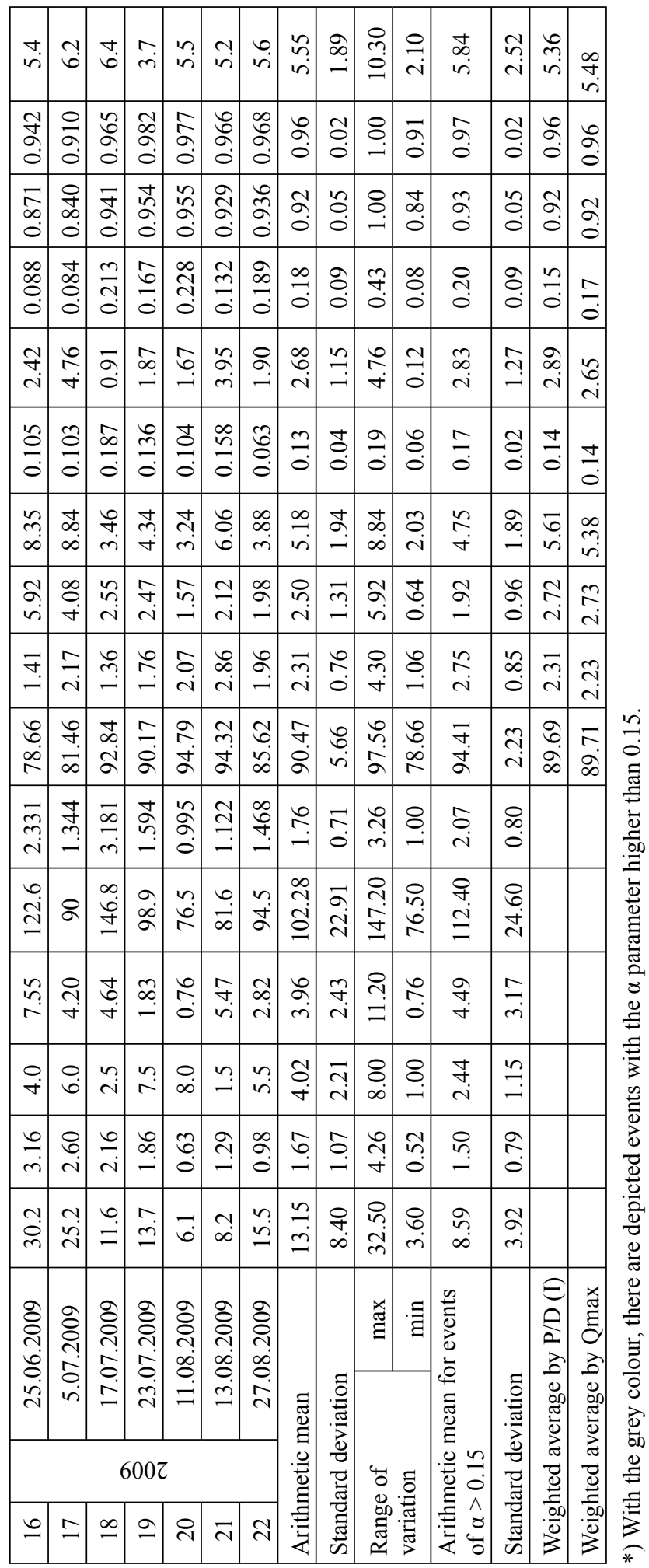


with a lower sum of precipitation (Fig. $4 a, b)$. Another statistical correlation was observed between $\mathrm{k}$ parameter and the sum of precipitation (total and effective), for events with a higher sum of precipitation $\mathrm{k}$ parameter achieves a higher value comparing with events with a lower sum of precipitation (Fig. 4d, f). Between lag time and duration of rainfall, as well as between $\mathrm{k}$ parameter and duration of
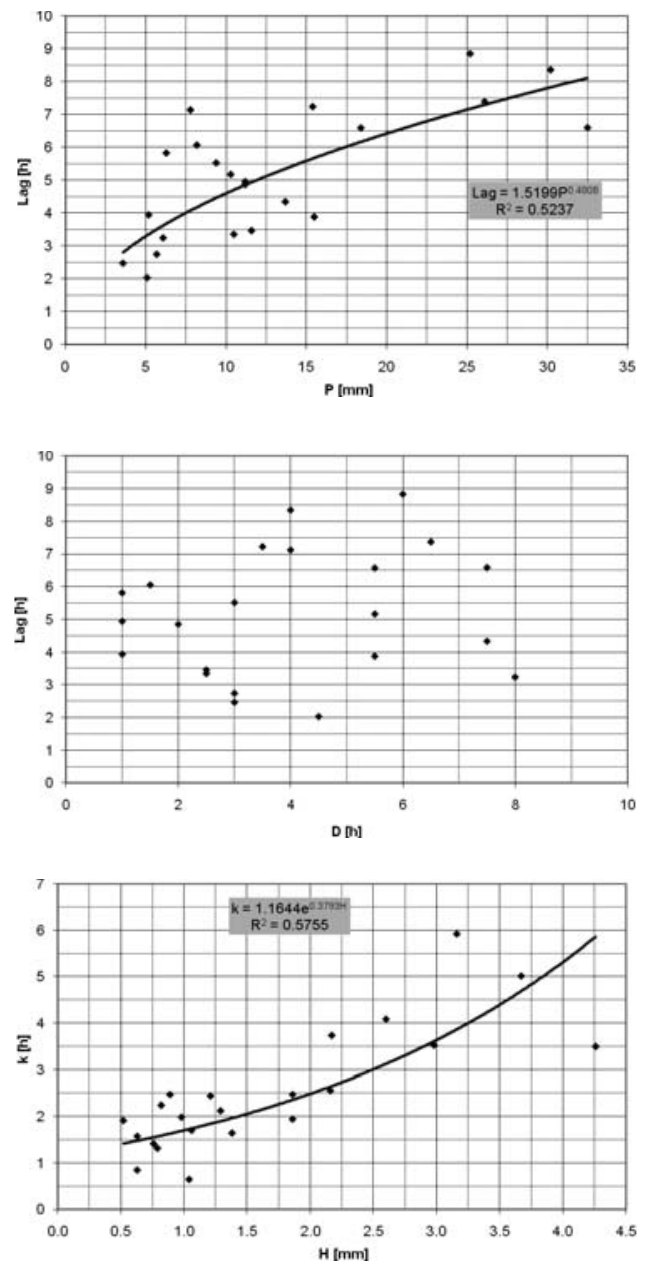

rainfall, no significant correlation was achieved (Fig. 4c, f).

\section{APPLYING OF THE RAO ET AL. METHOD AND RESULTS}

The Rao et al. method has been employed in research to evaluate the possibility of applying this method to estimate direct
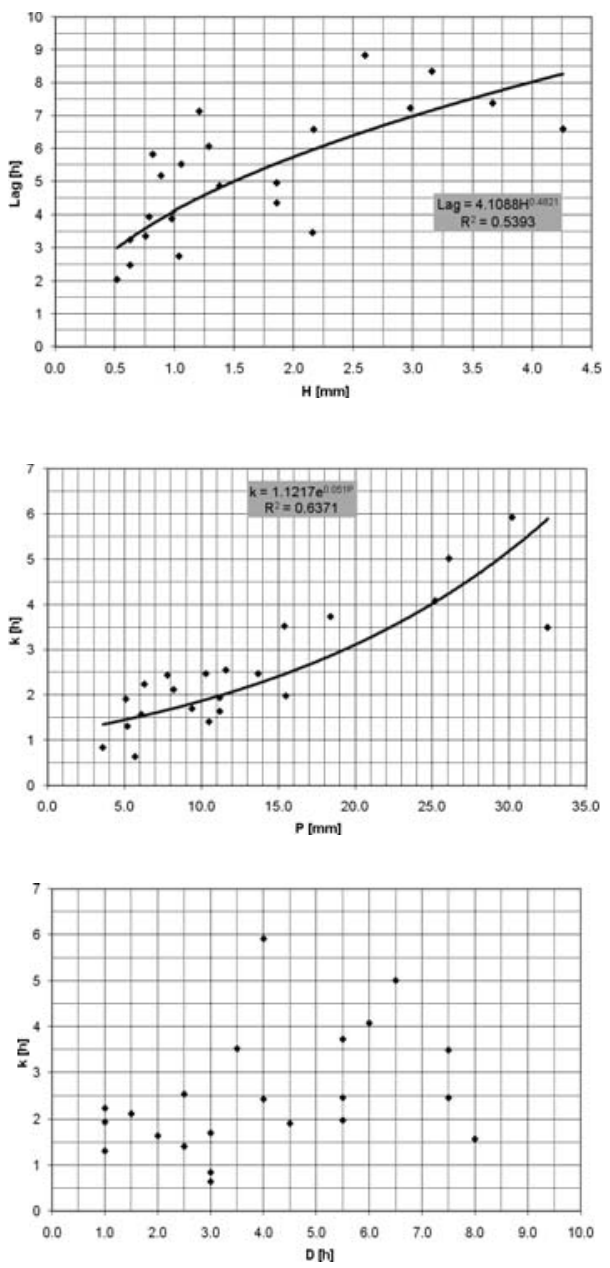

FIGURE 4. a-c: Relation between calculated Lag time based on sampled data (method of statistical moments), a) sum of a total precipitation $(\mathrm{P}), \mathrm{b}$ ) sum of an effective precipitation $(\mathrm{H}), \mathrm{c})$ duration of a rainfall (D). d-f: relation between calculated $k$ parameter d) sum of a total precipitation $(P)$, e) sum of an effective precipitation $(H)$, f) duration of a rainfall $(D)$ 


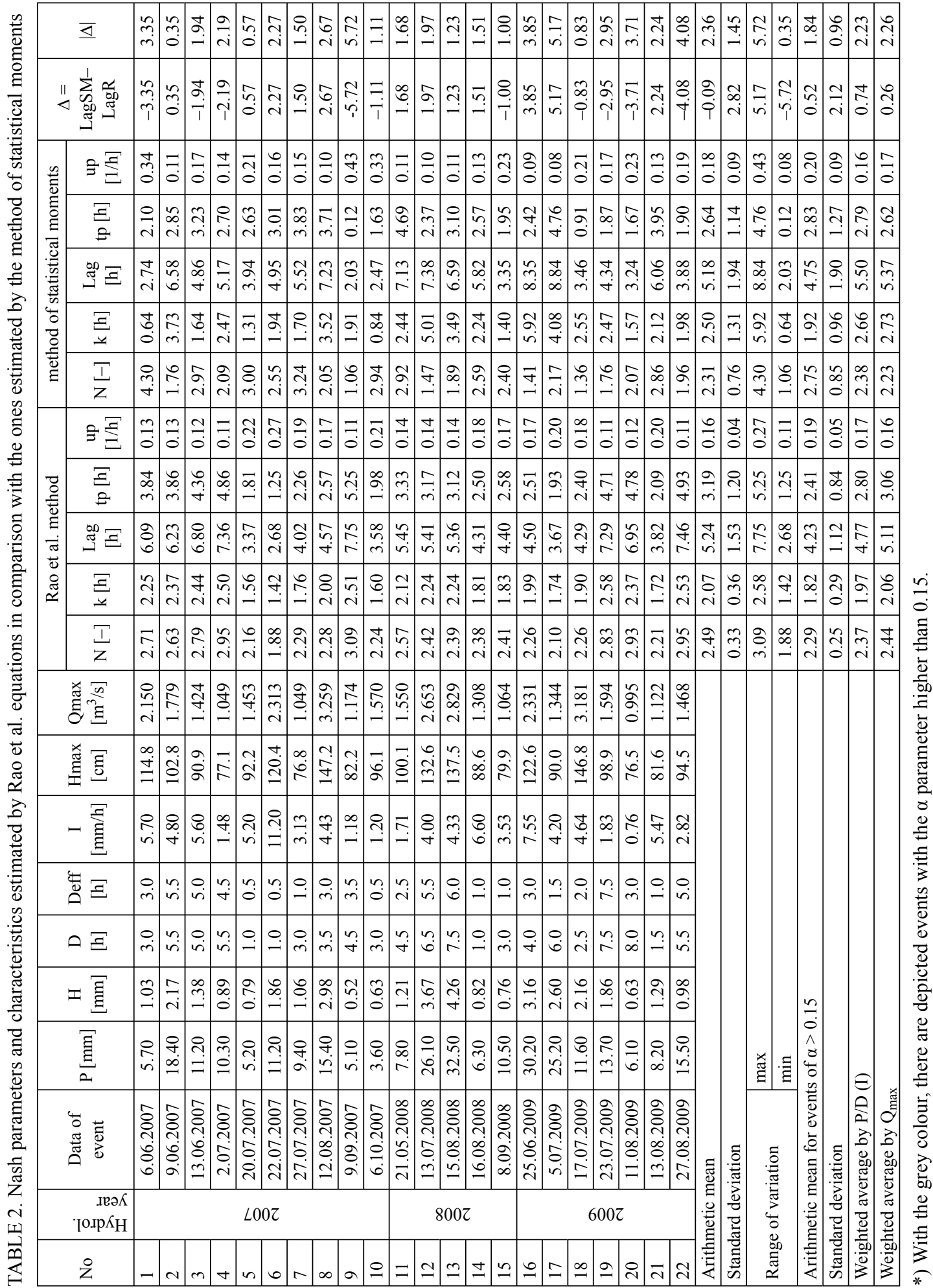


runoff on the basis of given rainfall (sum and duration of an effective rainfall) in a small urban catchment with partly or without any recorded data of runoff in the catchment. The comparison was made basing on a characteristic value of IUH (Lag time) estimated for both methods, the method of statistical moments (on recorded data of rainfall and runoff) and the Rao et al. method (only rainfall).

The results have shown (Tab. 2) that the mean lag time for chosen events estimated by Rao et al. equations (5.24 h) varies by less than $2 \%$ from the one estimated by the method of statistical moments $(5.18 \mathrm{~h})$, whereas the value of a mean lag time estimated by Rao et al. equations for the events with a high runoff coefficient (higher than 0.15) (4.23 h) varies by around $10 \%$ from the one estimated by the method of statistical moments $(4.75 \mathrm{~h})$. Considering lag times for both methods, there has not been established any simple relation between those two values (Fig. 5), although, the values of Lag for single events vary mean by $2.36 \mathrm{~h}$.

\section{DISCUSSIONS AND CONCLUDING REMARKS}

The aim of this paper was to identify parameters of a conceptual model for Sluzew Creek catchments; to verify how chosen characteristics of a model depend on chosen rainfall characteristics, and to compare an empirical method of estimating of Instantaneous Unit Hydrograph (IUH) by Nash model - Rao, Delleur and Sarma, with the one based on recorded data from three hydrological years (2007-2009). The Rao et al. method has been employed in research to estimate possibilities of applying this method in small urban catchment with limited or without any recorded data in the catchment, and a comparison was made based on characteristic values in IUH - Lag time.

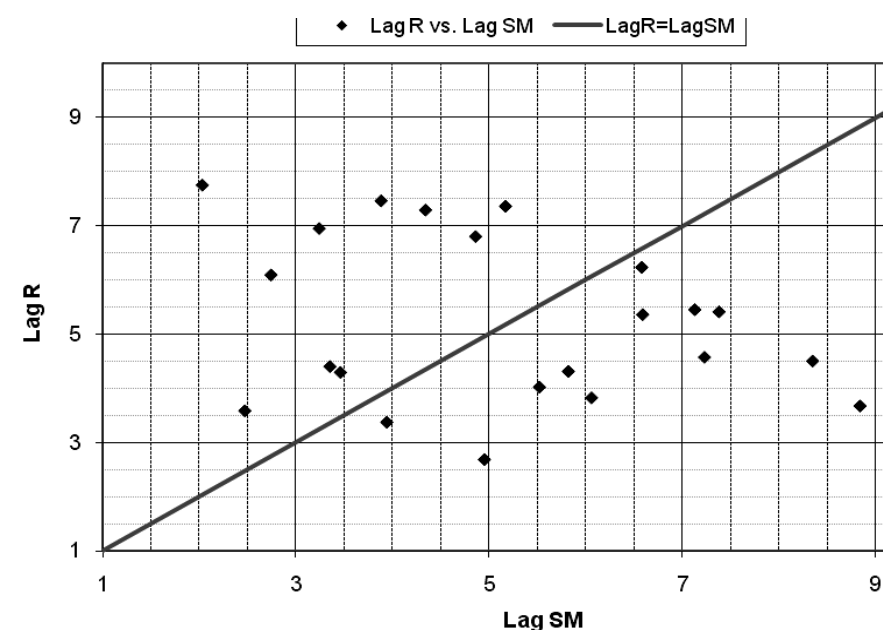

FIGURE 5. Relation between Lag times of recorded events estimated with the use of Rao et al. method vs method of statistical moments 
The results of identification and verification of characteristics values of IUH (Lag and k) for Sluzew Creek catchment, presented in this paper, have indicated a statistical correlation between lag time and the sum of total and effective precipitation, and between $\mathrm{k}$ parameter and the sum of total and effective precipitation as well. For events with a higher sum of precipitation a higher value of lag time has been observed (similarly for $\mathrm{k}$ parameter). The significant correlation between Lag time or k parameter and duration of rainfall has not been achieved.

Next, the conducted analysis has shown that mean IUH characteristic values ( $\mathrm{Lag}$ and $\mathrm{k}$ ) estimated with the use of Rao, Delleur and Sarma equation has given the promising results in comparison with the mean characteristic values of measured IUH. Moreover, Rao et al. method has given a better fit to sampled method for the events with a high value of runoff coefficient $(\alpha>0.15)$. However, the values of characteristic parameters for single events vary visibly.

The reason of differences between single values estimated by both methods, as well as for a relatively high value of Lag time as for a urban catchment can be given by a specificity of the catchment, which as an urban catchment with a partly built sewerage system has a limited possibility to drain the total amount of water during rainfall events, especially during events with a high amount of precipitation. Therefore, during those events, water might be hanged within the catchment, as it cannot be discharge in real time, and might be drained after the highest peak, when there will be a space for water in sewerage systems. Another explanation could be made by charac- teristic of a catchment, which, in upper part, consists in retention ponds (located under airport Okęcie area), which might have an influence on deletion of real lag time, as a consequence of collection and detention of water during rainfall events. That can also cause a relatively long time of Lag for the catchment as for an urban catchment. Therefore, the next step, which should be made in research, will be applying of the Rao et al. method for another catchment without any or with less strong possible influence of a retention pond on a response of a catchment to rainfall events. Consequently, the research needs a further investigation and verification by applying it for another set of data and other urban catchments.

\section{REFERENCES}

BANASIK K., BARSZCZ M., HEJDUK L. 2007: Current and perspective flood flow consequences of land use changes in Sluzew Creek (suburb of Warsaw). Special aspects of urban flood management, Proceedings Coast Session Aquaterra Conference 2007, Institut fur Wasserbau, Technische Universitat Hamburg, Harburg, 2007.

BANASIK K., GÓRSKI D., IGNAR S. 2000: Modeling of the runoff hydrographs and water quality from small ungauged agricultural catchments. Warsaw University of Life Sciences - WULS Press, Warsaw, Poland.

BARSZCZ M., BANASIK K., TÖNSMANN F. 2006: Estimation of Lag times of rainfall events for three small river basins. Electronic Journal of Polish Agricultural Universities, 2006, Volume 9, Issue 2, Topic: Environmental Development.

BEVEN K.J. 2000: Rainfall-runoff modelling: The Primer. Jon Wiley and Sons, West Sussex, UK. 
BEVEN K.J., KIRKBY M.J. 1979: A physically based, variable contributing area model of basin hydrology. In: Hydrological Sciences-Bulletin 24, 43-69, IAHS Press, Wallingford, UK.

DOOGE J.C.I. 2005: Bringing it all together. Hydrological Earth System Sciences 9, 3-14.

DOOGE J.C.I. 1959: A general theory of the unit hydrograph. In: Journal of Geophysical Research 64 (1), 241-256.

Engineer Manual, 1994: Engineering and Design - Flood-Runoff Analysis, Department of the Army U.S. Army Corps of Engineers Washington, DC 20314-1000.

JENG P.E., COON G.C. 2002: The form of instantaneous unit hydrograph of linear reservoirs, Journal of Irrigation and Drainage Engineering, Vol. 129, No 1, $11-17$.

JOVANOVIC J. 1986: Hydrologic approches In Urban drainage system modeling, Proceedings of the 3rd International Conference "Urban Storm Drainage" (eds Maksimiwic C. and Radojkovic M.), Pergamon Press, Oxford, UK, 185-208.

KIWRS, 2002: Banasik K. 2002: (ed.). Hydrological documentation of Służew Creek at the Przyczolkowa street (in Polish), Warsaw University of Life Sciences - SGGW, Dept. of Water Engineering and Environmental Restoration.

LUTZ W. 1984: Berechnung von Hochwasserabfluessen unter Anvendung von Gebietskenngrossen. Universiataet Karlsrühe, IHW 24: 235.

NASH J.E. 1957: The form of instantaneous unit hydrograph. In: Surface Water, Prevision, Evaporation. International Association of Sciences and Hydrological Publications 45, 114-121. IAHS Press, Wallingford, UK.

RAO R.A., DELLEUR J.W., SARMA S.P. 1972: Conceptual Hydrologic Models for Urbanizing Basins. W: Journal of the Hydraulics Division, Proceedings of the American Society of Civil Engineers, No HY7.
SCS (Soil Conservation Service), 1986. Urban hydrology for small watersheds. Tech. Report 55, US Dept. of Agric., Washington DC, USA.

SHERMAN L.K. 1932: Steramflow from rainfall by unit-graph metod. W: Engineering News Rekord 108, 501-505, The McGraw-Hill Companies, Inc.

SIKORSKA A., BANASIK K. 2008a. Wpływ stosowanej metody wyznaczania chwilowych hydrogramów jednostkowych (IUH) na dokładność oszacowania parametrów wezbrań w zlewni miejskiej [Influence of use of various methods of estimate Instantaneous Unit Hydrographs (IUH) on the accuracy of evaluation of parameters for an urban catchment]. Acta Scientiarum Polonorum, Architecture, No 7(4), 25-39, [Engl. summ.].

SIKORSKA A., BANASIK K. 2008b: Wyznaczanie czasu opóźnienia odpływu bezpośredniego w zlewni Potoku Służewieckiego na podstawie danych pomiarowych [Estimation of Lag times of direct runoff for a Służew Creek catchment on the base of recorded data] (Przegląd Naukowy Inżynieria i Kształtowanie Środowiska), No 4 (42), 19-29, [Engl. summ.].

SIKORSKA A., BANASIK K. 2009: Estimation of instantaneous unit hydrographs (IUH) for a small urban catchment with the use of various methods, Służew Creek catchment (Warsaw). Paper of the International Conference on Urban Flood Management 2009 - Final Conference COST Action C22 (European Cooperation in Science and Technology - Urban Flood Management).

SINGH V.P. 1988: Hydrologic Systems Vol. 1: Rainfall-runoff modeling. Prentice Hall.

Streszczenie: Identyfikacja parametrów modelu koncepcyjnego opad-odplyw matej zlewni zurbanizowanej. W wyniku rozbudowy miast warunki w zlewniach miejskich są stale zmieniane. Prowadzi to do wzrostu zagrożenia powodziowego na obszarze miejskim, w wyniku przepełnienia małych 
strumieni, które nie są przygotowane na przyjęcie większej ilości wody. Co więcej, dane hydrologiczne z długiego okresu czasu nie są zazwyczaj dostępne dla małych strumieni na terenach miejskich, a jeśli występują ograniczają się do kilku ostatnich lat lub do momentu, po wprowadzonych zmianach $\mathrm{w}$ zlewni $\mathrm{w}$ następstwie urbanizacji. W związku z tym, zastosowanie bezpośrednich metod wyznaczania przepływów wezbraniowych dla małych strumieni staje się prawie niemożliwe. $\mathrm{Z}$ tego powodu rośnie znaczenie modelowania matematycznego jako podstawowej metody oceny przepływów wezbraniowych w miastach o ograniczonej informacji o zlewni. Celem niniejszej pracy jest identyfikacja parametrów koncepcyjnego modelu procesu opad-odpływ w małych nieobserwowanych zlewniach miejskich i weryfikacja, jak wybrane charakterystyki modelu zależą od wybranych charakterystyk opadów. Wyniki modelowania prowadzonego w małej zlewni miejskiej - zlewni Potoku Służewieckiego (zlokalizowanego w Warszawie), zostały przedstawione $\mathrm{w}$ artykule. Zlewnia ta monitorowana jest przez Zakład Inżynierii Wodnej i Rekultywacji Srodowiska (SGGW) od kilku lat. Następnie przedstawiono wyniki porównania charakterystyk chwilowego hydrogramu jednostkowego (IUH) wyznaczonego wg metody Rao, Delleur i Sarma z charakterystykami IUH ustalonego na podstawie obserwowanych danych opad-odpływ. W metodzie Rao i współautorów, charakterystyki modelu uzależnione są od udziału powierzchni zurbanizowanych w zlewni, jak również czasu trwania i ilości opadu efektywnego. Ponadto, udział obszaru zurbanizowanego pozwala użytkownikowi na adaptację tej metody $\mathrm{w}$ prosty sposób do nowych warunków zlewni, co jest szczególnie istotne dla obszarów miejskich. Chwilowe hydrogramy jednostkowe wyznaczone zostały wg modelu
Nash, w którym zlewnia przedstawiana jest jako kaskady $\mathrm{N}$ zbiorników liniowych o tym samym parametrze retencji $\mathrm{k}$. Wydzielenie opadu efektywnego $\mathrm{z}$ zaobserwowanego przeprowadzono wg metody CN-SCS. Porównanie dwóch metod wyznaczania charakterystyk hydrogramów IUH zostało przeprowadzone na podstawie trzech lat hydrologicznych (2007-2009) dla profilu Staw Berensewicza, a porównania dokonano na podstawie wartości charakterystycznej IUH (lag - czas opóźnienia). Przeprowadzona analiza wykazała istnienie zależności statystycznej pomiędzy Lag i k a charakterystykami deszczy (wysokością opadu całkowitego i efektywnego). Ponadto, charakterystyki IUH wyznaczone wg równań Rao, Delleur i Sarma dają obiecujące wyniki w porównaniu z charakterystykami wyznaczonymi na podstawie zaobserwowanych danych. Dlatego metoda ta może być przydatna do oceny i przewidywania przepływów powodziowych w małych nieobserwowanych zlewniach miejskich w sytuacji ograniczonej informacji. Zagadnienie to wymaga jednak dalszych badań i weryfikacji.

Stowa kluczowe: chwilowy hydrogram jednostkowy - IUH, model Nasha, metoda Rao, Delleur i Sarma, CN-SCS, zlewnie obserwowane, czas opóźnienia (Lag).
Author's address:
Anna Sikorska
Katedra Inżynierii Wodnej i Rekultywacji
Środowiska
SGGW
ul. Nowoursynowska 159
02-787 Warszawa
Poland
anna_sikorska@sggw.pl 